\title{
Magnetic Resonance Imaging Department Cost Study: A Glance from Cyprus
}

\author{
Nicolas Nicolaou \\ Assistant Program Coordinator of Master in Public Administration, The Department of European Studies and International \\ Relations, University of Nicosia, Nicosia 1700 Cyprus
}

\begin{abstract}
MRI (Magnetic Resonance Imaging) usage tends to be rapidly increasing over the last decades in clinical applications. Although MRI service is a powerful and very useful diagnostic tool for the doctors, it is very expensive. This research paper concerns the economic cost of the NGH (Nicosia General Hospital) MRI Department for the calendar year 2015. Data were collected and analysed through triangulate data collection methods. Research methods include empirical observation, interviews and secondary data analysis. Calculations were made by the bottom-up method. The total cost for the MRI department for the year 2015 was $€ 434,987.52$. The external services bought from private sector in order to eliminate waiting list cost $€ 1,071,803$. In case NHIS (National Health Insurance System) was implemented in 2015 possible incomes should be €1,412,152. Nicosia General Hospital MRI department balance in case NHIS was implemented in 2015 was $€ 94,638.52$ loss. The negative result strongly supports that there is space for improvement in the MRI department. Our research suggests that changes must be done in the management of the MRI Department. Implementation of TQM (Total Quality Management) method could reduce the cost of the aforementioned diagnostic department. This work is the first cost study for the NGH MRI Department and could be used as a reference and give basic costing data for MRI service to healthcare policy makers.
\end{abstract}

Key words: MRI cost study, healthcare public sector, Cyprus.

\section{Introduction}

Over the last decades medical technology and medical devices in particular have undergone tremendous growth. MRI (magnetic resonance imaging) usage tends to rapidly increase to clinical applications such as diagnosis, prevention and treatment producers [1]. Although MRI service is a powerful and very useful diagnostic tool for doctors [2], it is very expensive as several studies show [3].

A cost study of a healthcare department contains the resources that are used for production as well as for distribution of the diagnostic healthcare services [4]. In our research study, the MRI department cost study contains the total resources needed for the production and distribution of MRI examinations of the NGH (Nicosia General Hospital) patients. More specifically

Corresponding author: Nicolas Nicolaou, Ph.D., research field: health care management. it includes human resources and consumables. According to OECD (2014) there are not enough MRI units per country and if their number is small, then an accessibility problem will be raised. Even though Cyprus has a high percentage of MRI units per population in Europe, there is only one MRI unit in the public sector [5]. Thus an accessible problem was raised due to the fact that the waiting list is more than 12 months [6].

The purpose of this research paper is to highlight the economic cost of the NGH MRI Department in Cyprus for the calendar year 2015. This study will provide important information to health policy makers and technocrats in Cyprus regarding real economic cost results as well as improvement solution for the aforementioned diagnostic department. This is even more important as Cyprus is a few steps away from the upcoming NHIS (National Health Insurance System) implementation. 


\section{Material and Methods}

Data were collected and analyzed through triangulate data collection methods. Research methods include empirical observation, interviews and secondary data analysis. Calculations were made with the bottom-up method [7].

We conducted empirical observation to the Nicosia General Hospital MRI Department for the period of 2 months with the view of an in-depth understanding of the internal procedures. Then all personnel categories (doctors, radiologic technologists, nurse and administrative staff) were interviewed in order to cross check those empirical observation's findings.

Next we calculated the consumables' total cost. We collected and analyzed data regarding the number of patients and examination type from the hospital's online database PACS (picture archive communication system). We found each examination frequency number. Then we analyzed each MRI examination procedure separately given that consumable usage is not the same in every examination. The contrast liquid total cost was collected from the pharmaceutical services. Information regarding consumable's cost was collected from the Ministry of Health Purchasing Directorate.

Furthermore, the total employees' cost was calculated including annual salary and overtime payment. In NGH MRI Department 7 professionals are employed, which are two physician radiologists, two radiologic technologists, one nurse and two administrative staff. Data regarding annually salary as well as overtime rate payment were collected from Republic of Cyprus Treasury and calculated accordingly. Information such as number and personnel category, overtime examinations' number and average salary scale were collected through empirical observation and interview methods.

Moreover an additional 20\% indirect cost in terms of miscellaneous expenses such as electricity, cleaning services, water and telecommunications were included [8].

Due to the fact that there was a long waiting list for MRI examination in 2015 [6], Ministry of Health bought external services from the private sector in order to eliminate waiting lists. Data regarding the cost of the external services were collected through interviews from Medical and Public Health Services Accounting Department's officers.

Finally, we calculated the possible MRI department income in case public healthcare services were covered and operated by NHIS. We collected information from Nicosia General Hospital's Accounting Office regarding the cost of each examination for patients that were not healthcare beneficiaries. The total number of patients per type of MRI examination was collected from the hospital's online database PACS and calculations were made accordingly.

\section{Results and Analysis}

The total number of patients for the MRI department for the year 2015 was 3,760 (Table 1). The total consumables’ cost was €32,799.92 (Table 2). The total employees' cost including annual salary and overtime payment was €329,689.68 (Table 3). The total cost for Nicosia General Hospital MRI department for the year 2015 was $€ 434,987.52$ (Table 4).

Table 1 Total number of patients for Nicosia General Hospital MRI Department for the year 2015.

\begin{tabular}{ll}
\hline Month & Patient number \\
\hline January & 297 \\
February & 309 \\
March & 347 \\
April & 296 \\
May & 328 \\
June & 325 \\
July & 313 \\
August & 320 \\
September & 321 \\
October & 311 \\
November & 292 \\
December & 301 \\
Total patient number for the year 2015 & 3,760 \\
\hline
\end{tabular}


Table 2 Total consumables' cost for Nicosia General Hospital MRI Department for the year 2015.

\begin{tabular}{|c|c|c|c|c|c|}
\hline Cost type & & $\begin{array}{l}\text { Total examinations } \\
\text { per examination type }\end{array}$ & Cost per unit in euro & $\begin{array}{l}\text { Total cost per } \\
\text { examination in euro }\end{array}$ & $\begin{array}{l}\text { Total cost for the } \\
\text { year } 2015 \text { in euro }\end{array}$ \\
\hline \multirow[t]{12}{*}{ Examinations } & Brain & 1,243 & 0.12 & 149.16 & \\
\hline & Spine & 1,241 & 0.06 & 74.46 & \\
\hline & Knee & 259 & 0.06 & 15.54 & \\
\hline & Cervical spine & 59 & 0.06 & 3.54 & \\
\hline & Abdomen & 274 & 0.12 & 32.88 & \\
\hline & Femur & 20 & 0.06 & 1.20 & \\
\hline & Chest & 18 & 0.06 & 1.08 & \\
\hline & Hips & 78 & 0.06 & 4.68 & \\
\hline & Ankle & 48 & 0.06 & 2.88 & \\
\hline & Shoulder & 146 & 0.06 & 8.76 & \\
\hline & Forearm & 17 & 0.06 & 1.02 & \\
\hline & Brain- cervical spine & 356 & 0.12 & 42.72 & 337.92 \\
\hline \multirow[t]{3}{*}{$\begin{array}{l}\text { Contrast liquid } \\
\text { (gadolinium) }\end{array}$} & $10 \mathrm{~mL}$ & 400 & 12.38 & $4,952.00$ & \\
\hline & $15 \mathrm{~mL}$ & 1,500 & 14.14 & $21,210.00$ & \\
\hline & $20 \mathrm{~mL}$ & 350 & 18.00 & $6,300.00$ & $32,462.00$ \\
\hline Consumable total cost & & & & & $€ 32,799.92$ \\
\hline
\end{tabular}

Table 3 Total employees' cost for Nicosia General Hospital MRI Department for year 2015.

\begin{tabular}{|c|c|c|c|c|c|c|}
\hline Employees & $\begin{array}{l}\text { Number of } \\
\text { employees }\end{array}$ & Salary scale & $\begin{array}{l}\text { Annual salary for } \\
1 \text { personin euro }\end{array}$ & $\begin{array}{l}\text { Annual salary for regular } \\
\text { payment per employee } \\
\text { categoryin euro }\end{array}$ & $\begin{array}{l}\text { Overtime } \\
\text { paymentin euro }\end{array}$ & $\begin{array}{l}\text { Total annually } \\
\text { costin euro }\end{array}$ \\
\hline & A & B & $\mathrm{C}$ & $\mathrm{D}=\mathrm{A} \times \mathrm{C}$ & E & $\mathrm{F}=\mathrm{D}+\mathrm{E}$ \\
\hline $\begin{array}{l}\text { Physician } \\
\text { Radiologist }\end{array}$ & 2 & A13 & $56,905.29$ & $113,810.58$ & $54,792.96$ & $168,603.54$ \\
\hline $\begin{array}{l}\text { Radiologic } \\
\text { technologist }\end{array}$ & 2 & A7 & $24,200.02$ & $48,400.04$ & $26,028.48$ & $74,428.52$ \\
\hline Nurse & 1 & A7 & $24,200.02$ & $24,200.02$ & $26,028.48$ & $50,228.50$ \\
\hline $\begin{array}{l}\text { Administrative } \\
\text { staff }\end{array}$ & 2 & A1 & 10,800 & $21,600.00$ & $14,829.12$ & $36,429.12$ \\
\hline Total cost & & & & & & $€ 329,689.68$ \\
\hline
\end{tabular}

Table 4 Total running cost for Nicosia General Hospital's MRI department for 2015.

\begin{tabular}{|c|c|c|c|c|c|c|}
\hline Cost type & Category cost & Description & Frequency & Amountin euro & $\begin{array}{l}\text { Total cost per } \\
\text { categoryin euro }\end{array}$ & $\begin{array}{l}\text { Total cost per } \\
\text { typein euro }\end{array}$ \\
\hline \multirow[t]{7}{*}{ Direct cost } & Annually salary & Physician radiologist & 2 & $56,905.29$ & $113,810.58$ & \\
\hline & & Radiologic technologist & 2 & $24,200.02$ & $48,400.04$ & \\
\hline & & Nurse & 1 & $24,200.02$ & $24,200.02$ & \\
\hline & & Administrative staff & 2 & 21,600 & 21,600 & $208,010.64$ \\
\hline & Overtime payment & Physician radiologist & 1 & $54,792.96$ & $54,792.96$ & \\
\hline & & Radiologic technologist & 1 & $26,028.48$ & $26,028.48$ & \\
\hline & & Nurse & 1 & $26,028.48$ & $26,028.48$ & \\
\hline
\end{tabular}


Table 4 continued

\begin{tabular}{|c|c|c|c|c|c|c|}
\hline Cost type & Category cost & Description & Frequency & Amountin euro & $\begin{array}{l}\text { Total cost per } \\
\text { categoryin euro }\end{array}$ & $\begin{array}{l}\text { Total cost per } \\
\text { typein euro }\end{array}$ \\
\hline & & Administrative staff & 1 & $14,829.12$ & $14,829.12$ & $121,679.04$ \\
\hline & \multirow[t]{2}{*}{ Consumable cost } & Consumable & & & 337.92 & \\
\hline & & Contrast liquid & & & $32,462.00$ & 32,799.92 \\
\hline Indirect cost & $\begin{array}{l}\text { Miscellaneous } \\
\text { expenses }\end{array}$ & $\begin{array}{l}\text { Cleaning service, water, } \\
\text { electricity, } \\
\text { telecommunications et }\end{array}$ & $\begin{array}{l}20 \% \text { of } \\
\text { direct cost }\end{array}$ & & $76,817.92$ & $76,817.92$ \\
\hline $\begin{array}{l}\text { Total } \\
\text { running cost } \\
\text { for } 2015\end{array}$ & & & & & & $€ 434,987.52$ \\
\hline
\end{tabular}

Table 5 Possible profit/loss for Nicosia General Hospital MRI Department in case NHIS was implemented in 2015.

\begin{tabular}{ll}
\hline Type of cost & Totalin euro \\
\hline Possible MRI department income for 2015 in case public healthcare services were covered and & $1,412,152$ \\
operated by National Health Insurance System & $432,987.52$ \\
Less: Total running cost for Nicosia General Hospital's MRI department for 2015 & $1,071,803$ \\
Less: Total cost for external services that bought from private sector in 2015 & $1,531,710.52$ \\
& $€-94,638.52$ \\
\hline
\end{tabular}

Table 6 Nicosia General Hospital MRI Department average cost per patient for 2015.

\begin{tabular}{ll}
\hline Total running cost for Nicosia General Hospital’s MRI department for 2015 in euro & $€ 460,907.5$ \\
\hline Total number of patients for Nicosia General Hospital’s MRI department for 2015 & 3,760 \\
Average cost per patient for 2015 in euro & $€ 122.58$ \\
\hline
\end{tabular}

In case NHIS was operated in 2015 possible incomes should be $€ 1,412,152$. Due to the fact that there was over 12 months waiting list, external services bought from private sector in order to eliminate waiting lists with cost €1,071,803. Lastly, Nicosia General Hospital MRI department balance in case NHIS was operated in 2015 was €94,638.52 loss (Table 5) and average cost per patient was €122.58 (Table 6).

\section{Conclusions}

The cost study of a healthcare service provides a clear view of possible profit or loss of the interested service [9]. According to the results for the Nicosia General Hospital MRI department average cost per patient was $€ 122.58$ for 2015. The Ministry of Health, as the public healthcare provider, spends $€ 1,505,790.52$ for MRI examinations services whereas the possible income of the aforementioned diagnostic service was $€ 1,412,152$ in case NHIS was implemented and operated in 2015 and examinations could be refunded from NHIS fund. Thus, the balance for Nicosia General Hospital MRI department for 2015 was $€ 94,638.52$ loss. The negative resultstrongly supports that there is space for improvement in MRI department.

Due to the fact that a negative balance is not viable for the diagnostic department, crucial changes must be taken. Changes regarding management have to be done, since our empirical observation and interview's findings showed that there is not any management method, approach or philosophy followed to the MRI department. TQM (Total Quality Management) could reduce the cost to the aforementioned diagnostic department [10]. According to the literature, many healthcare departments worldwide have implemented 
TQM in order to reduce cost of their service [11-15]. Specifically, George Washington University Hospital located in Washington, D.C. USA had reduced by 75,000 USD the cost as a result from TQM implementation [16]. In addition, Florida Hospital in Orlando USA had reduced the cost by 4,000,000 USD annually after TQM implementation [17].

The novelty of this research paper is that it's the first cost study for Nicosia General Hospital MRI Department. Until now, the Ministry of Health had data regarding healthcare sector's cost in general. But it did not have any data regarding the MRI department's cost solely. According to the literature the unknown cost is larger than the known cost [18]. Unknown cost could arise many problems regarding internal procedure changes and generally in strategic planning. In addition, this paper could help the Ministry of Health's attempts for costing each healthcare service separately. Due to the upcoming NHIS implementation Ministry of Health is trying to determine healthcare cost for each healthcare service solely. This study could be used as a reference and give basic costing data for an updated cost study.

\section{References}

[1] Scherzinger, Ann, and William Hendee. 1985. "Basic Principles of Magnetic Resonance Imaging —An Update.” High Tech Medicine 143: 782-92.

[2] Schersten, T., and Sisk, J. E. 1985. "An International View of Magnetic Resonance Imaging and Spectroscopy.” International Journal of Technology Assessment in Health Care 3: 1.

[3] Cherryman, G. 1985. "Cost of Operating a Nuclear Magnetic Resonance Imaging System.” British Medical Journal 291: 1437-8.

[4] Vieneris, G. 1986. Accounting Cost. Athens: Smbilias.

[5] OECD. 2014. "Medical Technologies: CT Scannaers and MRI Units.” In Health a Glance. Europe, 68-9. Paris:
OECD Publishing.

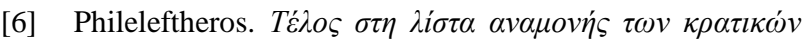

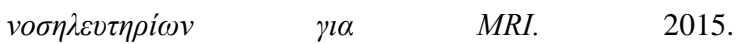
http://archive.philenews.com/el-gr/koinonia-eidiseis/160/ 278362/telos-sti-lista-anamonis-ton-kratikon-nosileftirion -gia-mri (accessed August 11, 2017).

[7] Finkler, S., and Ward, D. 1999. Essentials of Cost Accounting for Health Care Organizations. Aspen Colorado: Jones \& Bartlett Learning.

[8] Morfonios, A., Kaitelidou, D. Mbaltopoulos, G., and Miriantheus, P. 2011. "Medical-Social and Economic Effects of CT and the Evolution of Cross-Sectional CT's." Archives of Hellenic Medicine 28 (6): 767-76.

[9] Gyldmark, M. 1995. "A Review of Cost Studies of Intensive Care Units: Problems with the Cost Concept.” Critical Care Medicine 23 (5): 964-72.

[10] Ovretveit, J. 2000. "Total Quality Management in European Healthcare.” International Journal of Health Care Quality Assurance 13 (2): 74-9.

[11] Kunst, J., and Lemmink, J. 2000. “Quality Management and Bussiness Performance in Hospitals: A Search for Success Parameters.” Total Quality Management 2: 193-20.

[12] Kozak, M., Asunakutlu, T., and Safran, B. 2007. “TQM Implementation at Public Hospitals: A Study in Turkey." International Journal of Production and Quality Management 2: 193-207.

[13] Al-Marsumi, M. 2007. "Total Quality Management in a Chosen Section of the Hospitals in Amman Jordan.” Quality Management Journal 14: 45-7.

[14] Miller, W. J., Summer, A. T., and Deane, R. H. 2009. "Assessment of Quality Management Practises within the Healthcare Industry.” Americal Journal of Economics and Business Administration 1 (2): 105-13.

[15] Counte, M. A., Glandon, G. L., Oleske, D. M., and Hill, J. P. 1995. "Improving Hospital Performance: Issue in Assessing the Impact of TQM Activities.” Hospital and Health Services Administration 40 (1): 80-94.

[16] Chaufournier, R., and Andre, C. 1993. "Total Quality Management in an Academic Health Center.” Quality Progress Journal 26 (4): 63-6.

[17] Lumsdon, K. 1993. "Hospital Suppliers Put TQM to the Test.” Hospitals 67 (6): 58-9.

[18] Deming, E. W. 1986. Out of the Crisis. Massachusett: The MIT Press. 